\title{
Construing The Great Fire of London through online media: A case of exploring discourse semantics and register
}

\author{
Lungguh Ariang Bangga \\ English Literature Program, Faculty of Literature, Culture, and Communication Studies \\ Universitas Ahmad Dahlan, Jalan Ringroad Selatan, Tamanan, Banguntapan, Bantul, Yogyakarta, 55191
}

\begin{abstract}
This paper considers the exploration of genre and register of historical texts recontextualised in online media and school textbooks through the lens of Systemic Functional Linguistics especially by exploring their discourse semantics and register features. Particularly, this paper shows how the relation between discourse semantics resources and register variables contribute to the overall organisation of the recontextualized history genres. This paper provides a detailed qualitative analysis of discourse semantics as instantiated in the deployment of APPRAISAL, IDEATION, IDENTIFICATION, and PERIODICITY to give a clearer picture of how history genres in the media are established. A set of corpora consisting of historical texts from online media and school textbooks was used as a main source of data in this study. The historical texts collected from online media were from various platforms including online newspapers, online magazines, encyclopaedia entries, and universities websites/blogs. For the illustrative purposes, two texts from the corpora were selected for a detailed analysis using the discourse semantics toolkits to find out similarities and differences in terms how an historical event - The Great Fire of London - was established. The analysis found that there was a tendency that historical events could be reconstrued in the media through different ways. The first text informs readers about the fire and its significance in a chronological manner. The second text provides an explanation of the influence of the Great Fire to other historical events. This paper also suggests that history genres tend to be 'evolving' as reproduced in varied media discourses. Though still at the infancy stage, this paper offers a great insight into how genres are organised in relation to the choices in register variables and discourse semantics.
\end{abstract}

Keywords: Discourse semantics; genre; history; media; register; Systemic Functional Linguistics

\begin{tabular}{|ccc|}
\hline \hline First Received: & Revised: & Accepted: \\
7 February 2020 & 26 April 2020 & 25 May 2020 \\
Final Proof Received: & & Published: \\
31 May 2020 & 30 September 2020 \\
\hline How to cite (in APA style): & \\
Bangga, L. A. (2020). Construing The Great Fire of London through online media: A case of \\
exploring discourse semantics and register. Indonesian Journal of Applied Linguistics, 10(2), \\
406-419. https://doi.org/10.17509/ijal.v10i2.28612
\end{tabular}

\section{INTRODUCTION}

The discourse of history has been a central interest in both education and public domains. Its significance permeates people's life, contributing to the establishment of identity, affiliation, and collective memories (Coffin, 2006a). In the public domain, the discourse of history is often presented dramatically by the media (Coffin, 2003). Not surprisingly, the discourse of history plays a key role in aligning cultural consensus by delivering certain evaluative meanings, often relating to specific political and social values, that need to be accepted by its audiences (Oteíza, 2020; Oteíza \& Pinuer, 2013).

Historical discourses have been a prominent research interest for Systemic Functional Linguists over the past two decades. Research on historical discourses utilising Systemic Functional Linguistics (hereafter SFL) perspective has given significant contributions to the understanding of the nature of knowledge in the discipline of History as well as on the development of educational linguistics 
informing the teaching of History (Christie \& Derewianka, 2008; Coffin, 2004, 2006b; Schleppegrell, 2004). The initial agenda of investigating historical discourses in this tradition began during the 90's through Write It Right project (Coffin, 2004; Halliday \& Martin, 1993; Martin \& Veel, 1998). At this stage, the investigation focused on the exploration of historical genres in terms of their typical linguistic features and metalanguages required by the students to raise their control and awareness of different historical text types they faced in secondary education. Result wise, this was an important breakthrough as by delivering explicit metalanguages of historical genres to students, it helps them to systematically and critically reflect on the texts they read and write (Coffin, 2006a) thus contributing to their success in meeting the curriculum requirements. In relation to the purpose of this paper, such achievements can inform the analysis presented in this paper with regards to the development of history genres established in online media.

Current works on the investigation of historical discourses through SFL frameworks have been providing a critical input into how symbolic constructions of time link to the legitimation of particular collective memories of the past (Oteíza, 2020; Oteíza \& Pinuer, 2013). Such construction can be approached from either a combination or accumulation of lexicogrammatical resources or discourse semantics resources, or both resources. Through an exhaustive discourse semantics and lexicogrammar analysis, Oteíza and Pinuer (2013) indicate that the reconstruction of historical discourses in Chilean history textbooks allows for a 'scenification' (p. 43) of the past which in turn can legitimate authors' perspectives towards historical and collective memories. In addition, the deployment of SFL in investigating historical discourses can inform the enactment of history education (Martin \& Matruglio, 2020; Matruglio, Maton, \& Martin, 2013). In this particular area, SFL analysis offers the way to unpack technicality in History through the exploration of register variable field which is beneficial to elucidate the intricacy of knowledge building in this discipline. Furthermore, in terms of discourse semantics, especially APPRAISAL, Myskow's studies on Canadian history textbooks $(2017,2018)$ become an important input for revealing the complexity in which 'discourse participants put forward a range of evaluations towards historical events or subjects' (Myskow, 2018, p. 335). The extension includes a refinement on APPRECIATION features in APPRAISAL frameworks, as well as the inclusion of different levels of evaluation e.g. extra-, super-, inter-, and meta-evaluations (see Myskow, 2018 for further details of levels of evaluation).

Current research utilising SFL in online media tend to focus on the investigation of sport discourse
(Caldwell et al., 2016), affiliative bonding in newspaper editorials (Liu, 2018), the construal of subjectivity in social media (Zappavigna, 2016), news values (Bednarek \& Caple, 2017), and the discourses around education (Bangga \& Lukmana, 2019), to mention just a few. Historical discourses recontextualised through online media are not without any importance. Given the concern of the appliability of SFL in online media is about understanding how language constructs meaning (Carvalho, 2008; Feez, Iedema, \& White, 2008; Zappavigna \& Martin, 2018), it is then important to also investigate how history is semiotically constructed in online media.

This paper provides detailed explorations on discourse semantic resources, register, and genres making up history texts in online media from the vantage point of SFL in relation to the development of history genres established in online media. The study reported in this paper is a part of a larger study investigating historical discourses embedded in government-endorsed English language teaching textbooks and online media. This paper presents and discusses results of analyses of historical texts focusing on online media utilising discourse semantic toolkits e.g. APPRAISAL ${ }^{\mathrm{i}}$, IDEATION, IDENTIFICATION, and PERIODICITY (Martin \& Rose, 2007) to find out and argue for the differences and similarities of meaning making resources in the texts. Results of the analyses can be taken into account to identify the tendency of genre organisation of the recontextualised historical texts in online media. In working for the purpose of this paper, the next section of this paper turns its attention into describing the toolkits utilised to explore the texts and their relations to the configuration of genre.

\section{Discourse semantics toolkits}

Discourse semantics refers to the stratum of meaning that links lexicogrammar and context (register and genre) (Martin, 2019). The model of discourse semantics assumed in this paper follows that of Martin (1992), Martin and Rose (2007), and Martin and White (2005). This model has been a powerful model for interpreting social discourse, by considering the interplay between texts and social contexts (see e.g. Coffin, 2003; Martin, 2003) in especially shedding lights on how language (and other semiotic modes) works in context i.e. description of languages other than English (see Bangga, 2018; Martin, 2018; Zhang, 2020), the discourse of biology (Hao, 2015), the discourse of physics (Doran, 2018), and educational linguistics (Derewianka \& Jones, 2012; Dreyfus et al., 2016; Emilia, Habibi, \& Bangga, 2018; Kartika-Ningsih \& Rose, 2018; Rose \& Martin, 2012) among others. The model works above the meaning of language at clause level (lexicogrammar) (see Figure 1 for an illustration of different strata of language and 
context assumed in SFL) - comprising six major systems in relation to metafunctions i.e. IDEATION and CONJUNCTION, later refined and re-termed as "CONNEXION" (Hao, 2015, p. 118), designed for reifying the organization of ideational meanings; APPRAISAL and NEGOTIATION for interpersonal meanings; and IDENTIFICATION and PERIODICITY for textual meanings in a discursive event. In this paper, four major systems (IDEATION, APPRAISAL, IDENTIFICATION, PERIODICITY) are deployed to explore historical genres in online media.

\section{Figure 1}

Strata of Language and Context in SFL adapted from Martin (1992)

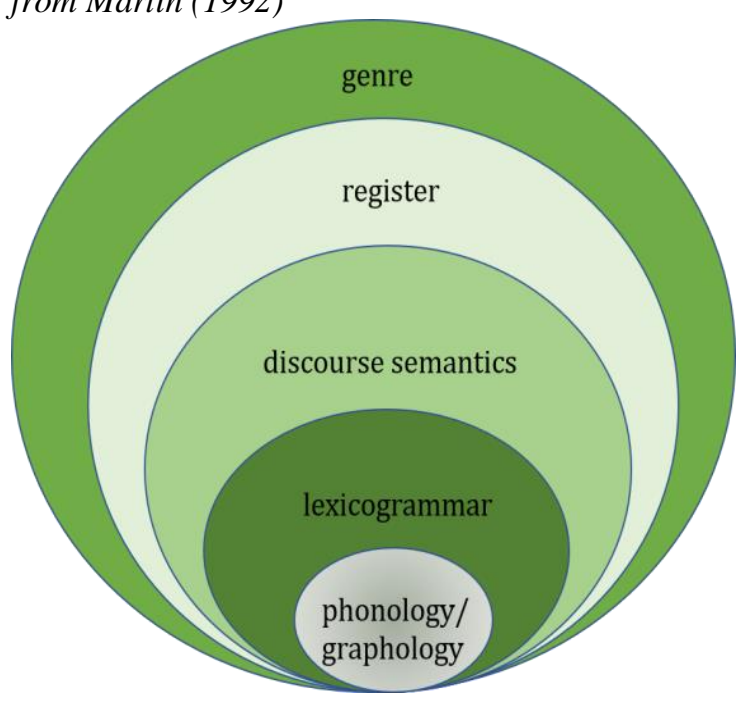

According to Martin and Rose (2007), IDEATION focuses on the construal of experiences in discourses - ideational meanings. It deals with sequences of activities, participants involved, and circumstantiation that link to the register variable field. In addition, IDEATION organises relations between the elements previously mentioned into sets of taxonomic relations; nuclear relations, that concern the centrality among processes, participants, and circumstances in discourse; and activity sequences. APPRAISAL is responsible for the enactment of interpersonal meanings in discourse and relates to register variable tenor. This has to do with feelings, evaluation towards people and their behaviours, and assessment of things and phenomena as well as the sourcing of evaluations (Martin \& White, 2005). IDENTIFICATION and PERIODICITY concern textual dimensions of discourse, and in turn construes register variable mode. The former works as tracking device introducing participants in discourse and keeping track of them. The latter has to do with information flow. They are responsible for managing the culmination of meanings in a text as a wave of information. The choices in all the systems mentioned above has a significant role in the establishment of genre and register organisations.

\section{METHOD}

A qualitative discourse analysis informed by SFL (Martin \& Rose, 2007, 2008) was deployed to explore the organisation of history texts recontextualised in online media. The analysis of such texts reported in this paper specifically took IDEATION, APPRAISAL, IDENTIFICATION, and PERIODICITY as the point of departure. Two texts from a set of corpora consisting of history texts from online media and school textbooks were selected as examples to illustrate how history texts were recontextualised in the media by especially comparing the discourse semantics resources of those texts. Figure 2 illustrates the interplay between those systems in discourse.

\section{Figure 2}

A General Outlook of Discourse Semantics Toolkits Adapted from Doran and Martin (2020a, p. 13)

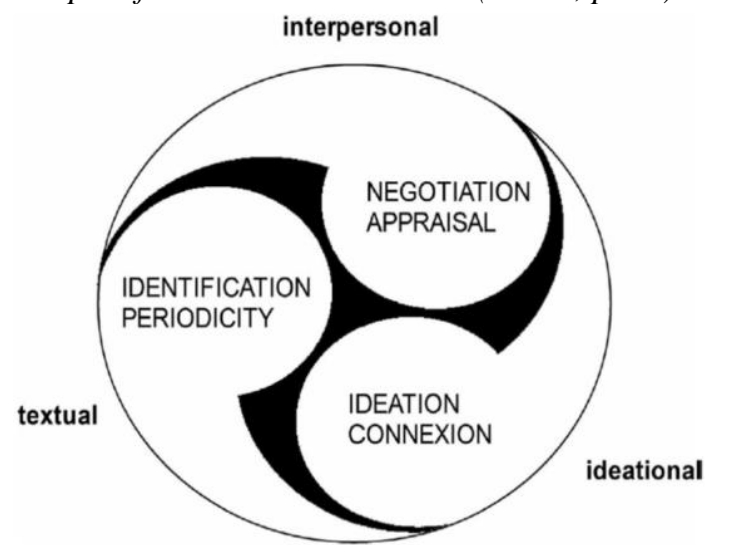

A set of corpora consisting of historical texts from online media, which included online newspapers, online magazines, encyclopaedia entries, and universities websites/blogs; and school textbooks was used as a main source of data. The texts vary in terms of genre, ranging from historical recounts to historical explanations. However, for an illustrative purpose, only two texts were selected from the corpus for a detailed analysis. The topic of the texts deals with an historical event Great Fire of London. Text 1, entitled Great Fire of London was an online encyclopedia entry informing in general about a bad fire that happened in London in September 1666 (The Editors of Encyclopaedia Britannica, 2014). Text 2, entitled The Plague, Australia, and The Great Fire of London (Morris, 2017), was a soft-news story that appeared in National Geographic website. These texts were selected for their interesting events. The Great Fire was an important event in the development of modern London, especially some related impacts on the city planning, fire management, and Londoners' resilience in facing disasters (Garrioch, 2016). In addition, the historical event of great fire captured larger attention interdisciplinarily. It has been explored in other disciplines such as medieval 
archaeology (Jeffries et al., 2014) and the history of emotions (Trigg, 2016). Furthermore, at a glance, these two texts tend to have common characteristics in terms of events presented; however, at a closer look, the configuration of meanings making up these texts seemed to be significantly different. Text 1 recorded the event of Great Fire, while Text 2 presented sort of cause-and-effect relations of Great Fire to Australia.

The two texts selected were analysed in detail to look at relations between discourse semantics resources and register variables. IDEATION analysis, which consists of activity sequences and taxonomy analyses, was deployed to explore experiential meanings. This in turn related to the register variable of field, that has to do with the construal of the world through a set of relations between participants, activities, and any associated qualities and circumstances oriented to some global institutional purposes (Martin \& Rose, 2007). The configuration of meanings within this variable maps the texts under the analysis into two-dimensional axes: activity - non-activity structured and general specific clines (see Martin \& Rose, 2008).

In analysing interpersonal meanings, APPRAISAL was used to investigate the way in which language construes interpersonal relations between interlocutors, which in turn contributes to the establishment of tenor. Based on this perspective, social relations were mapped onto two-dimensional axes realising status (equal - unequal) and solidarity (distance - close) (Martin, 1992; Martin \& Rose, 2008).

In analysing textual meanings, IDENTIFICATION and PERIODICITY were deployed to look at the way in which language plays in weaving the interpersonal and ideational meanings, which in turn relates to the configuration of mode. Mode refers to the role that language plays in the discourse. The analysis focused on dividing the role of language into two categories: monologic vs. dialogic and accompanying vs. constituting field (Martin \& Rose, 2008).

Figure 3

Taxonomy of Place in Text 1

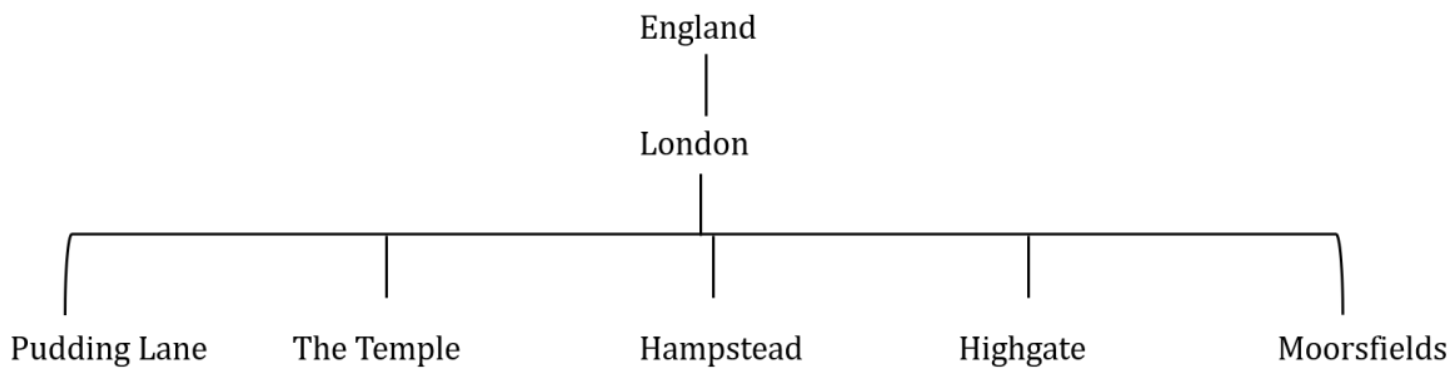

\section{FINDINGS AND DISCUSSION}

This section shifts gears into the findings and their discussion focusing on the similarities and differences between Text 1 and Text 2 . The discussion in this section is organised into several sub-sections, following register variables in discourse e.g. field, tenor, and mode. The discussion regarding overall organisations of genre of Text 1 and Text 2 is provided at the end of this section.

\section{Field}

There were two foci that are foregrounded in IDEATION analysis: taxonomy and activity sequences. The two texts established The Great Fire of London through different ways. Text 1, which was an online encyclopaedia entry, focuses on the sequences of fire, circumstances, doers, as well as classification of buildings, people, and places. Text 2 , at glances, seems to have a similar focus in terms of circumstances, doers, and classification. However, this text tends to construe a cause-effect relation in that The Great Fire contributes to several historical events. In terms of taxonomy, the classification can be observed in a relatively implicit manner, through generalised participants; different from the construal of classification that is found in the discipline of science (Martin, 2013a; Matruglio et al., 2013).

\section{Classification/taxonomy of places and buildings}

As far as the results of the analysis were concerned, both texts tended to have similar taxonomies in terms of place, buildings, and people involved in the texts. Looking closely at composition taxonomies, both texts construed London as the central point of fire by pointing out several affected places such as Pudding Lane, Hampstead, Thames Street and so on. Such taxonomy of places indicates the construal of specific component of the field, foregrounding specialisation of knowledge in history (Macnaught et al., 2013; Martin, 2013a; Matruglio et al., 2013). They are construed through material objects referring to particular historical time and places. The taxonomy of places can be seen in Figure 3 and Figure 4. 


\section{Figure 4}

Taxonomy of Place in Text 2

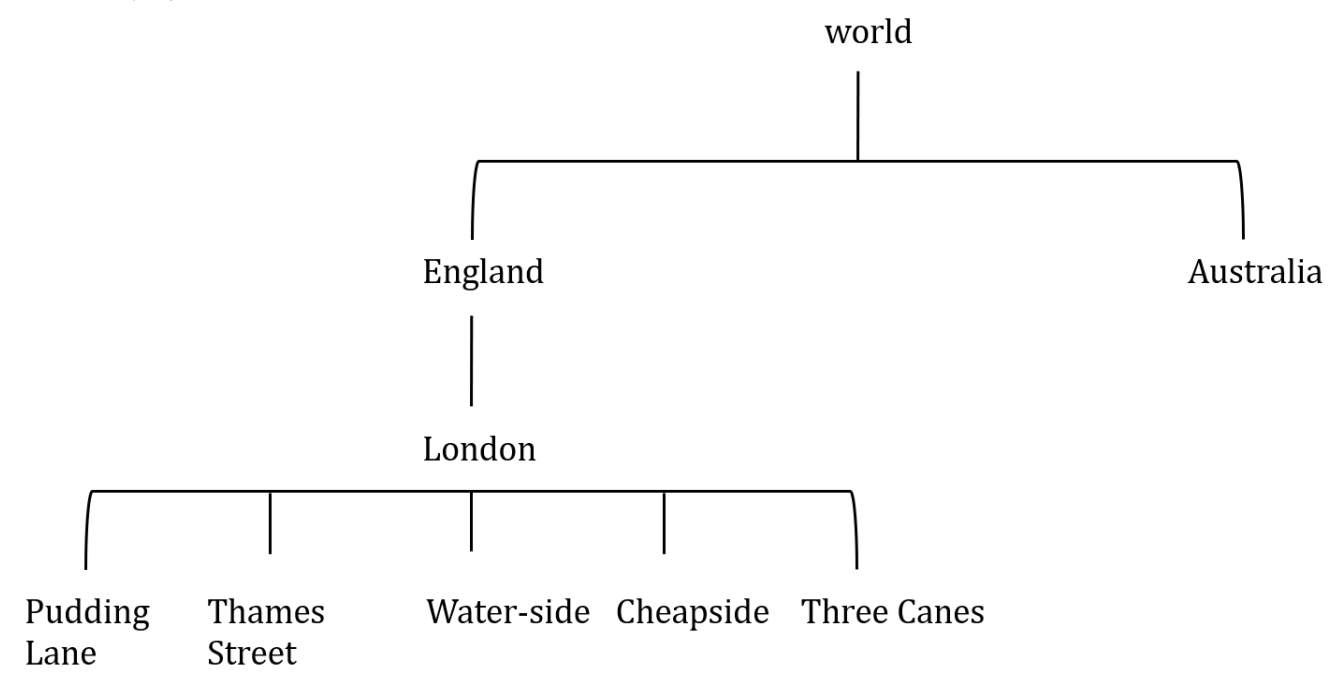

In addition to construing places affected by the fire, the texts also foregrounded taxonomies about buildings. Among other things, Text 1 created two contrastive examples of building domains: public and private. Public buildings, such as civic houses, churches, and civic houses, were notably highlighted in both texts as places impacted by the fire. These buildings were commonly realised by generic nominal groups. Private buildings, specifically the house of King's baker, contrastively, was realised by specific nominal groups, presuming that the readers shared similar knowledge about it.
Text 2 provides a more general classification of buildings in that most of them were realised through generic nominal groups and some proper nouns indicating that the text was directed to a very specific group of audiences. The use of such nominal groups contributes to the establishment of genericity of the field of history (Martin, 2003, 2013a) in that, alongside specialised terms as shown through places, historical texts in online media are also directed to a more global readerships. The examples of classification of buildings construed in the texts are provided in Figure 5 and Figure 6.

\section{Figure 5}

Classification of Buildings in Text 1

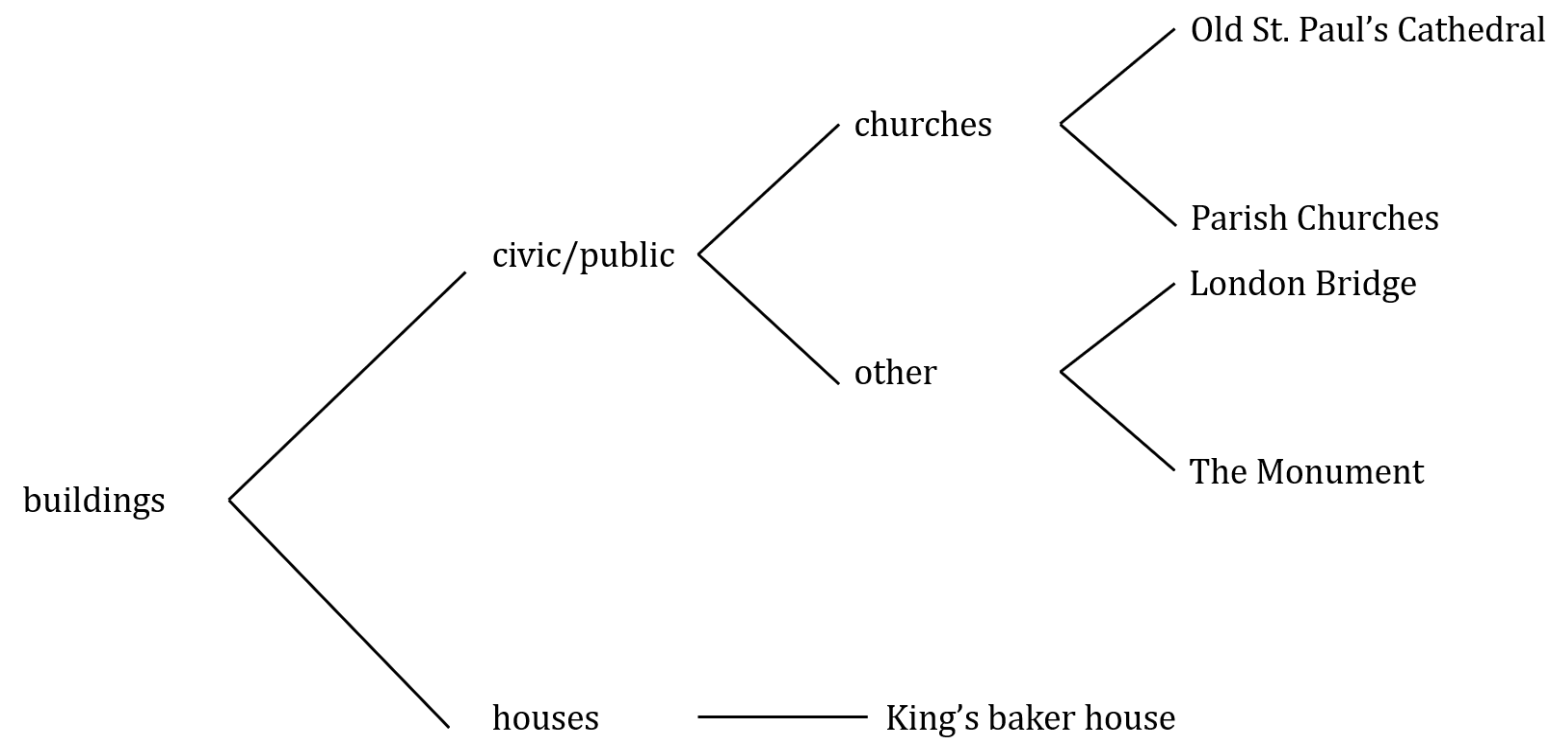




\section{Figure 6}

Classification of Buildings in Text 2

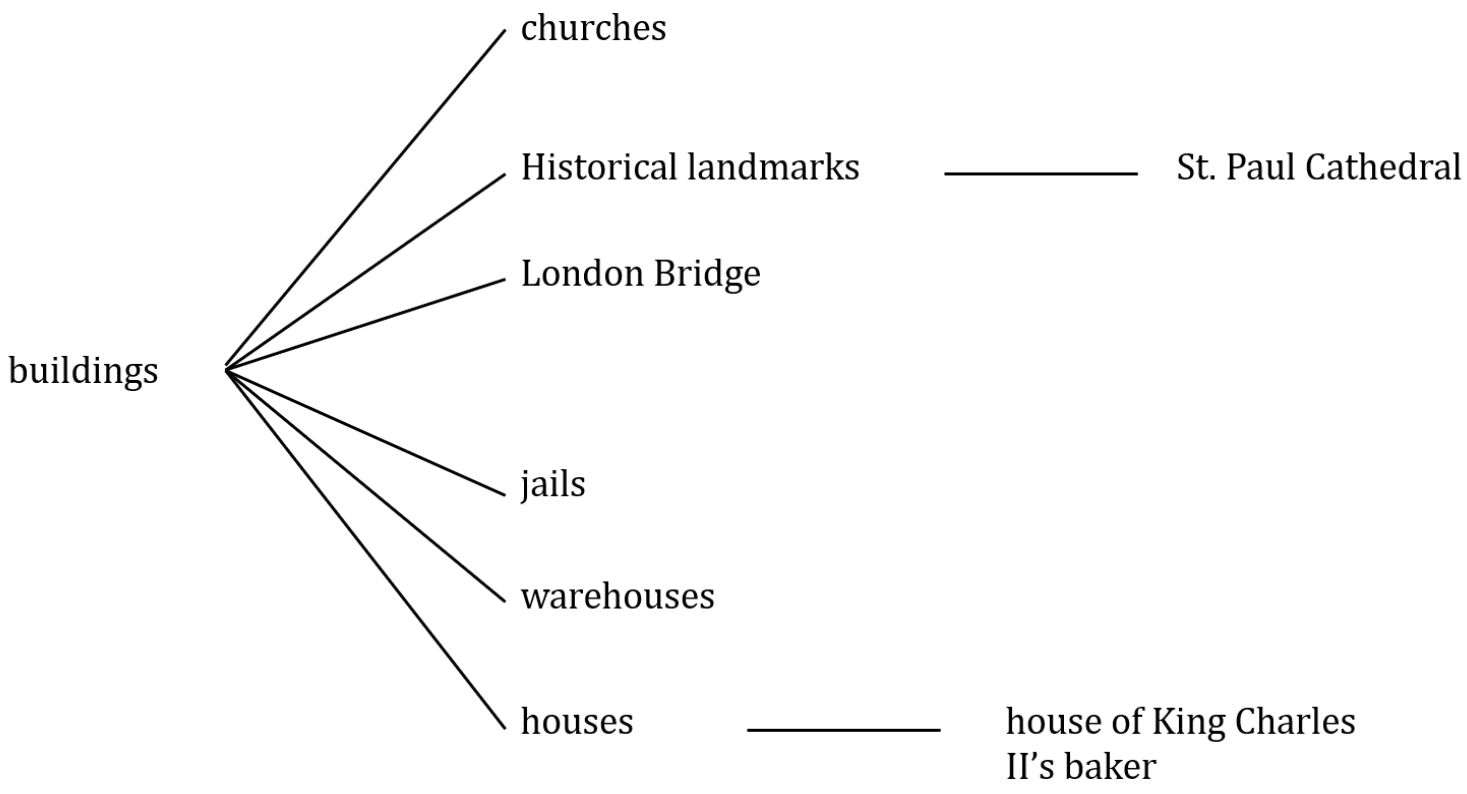

Another taxonomic relation that was construed by the texts was of the people involved in the events (see Figure 7 and Figure 8). Both texts focused on British people realised through naming and

In addition to taxonomizing places and buildings, one salient element constituting the field of history within both texts was the use of generalised participants and specialised lexis. Some examples of generic participants referred in the texts were historical events, public houses, houses, churches, vessels, goods, and so on. In addition, Text 2 makes explicit the field that is built up by using a field-specific lexis e.g. colonialization, invasion, and infiltration. Furthermore, the use of specific proper nouns, such as The Great Fire and

generalised mass participants. In addition, Text 2 presented other types of people referred generally to historians.

The Black Death can also be considered as specialised lexis in historical discourse, thus characterising the field into an uncommon sense one. The use of such nominal groups, as well as specialised lexis, indicates that the field of history moves a step forward towards uncommon-sense understanding (Martin, 2003), creating technicality and specialisation of knowledge (Martin \& Maton, 2013; Martin \& Matruglio, 2020; Matruglio et al., 2013).

\section{Figure 7}

Classification of People in Text 1

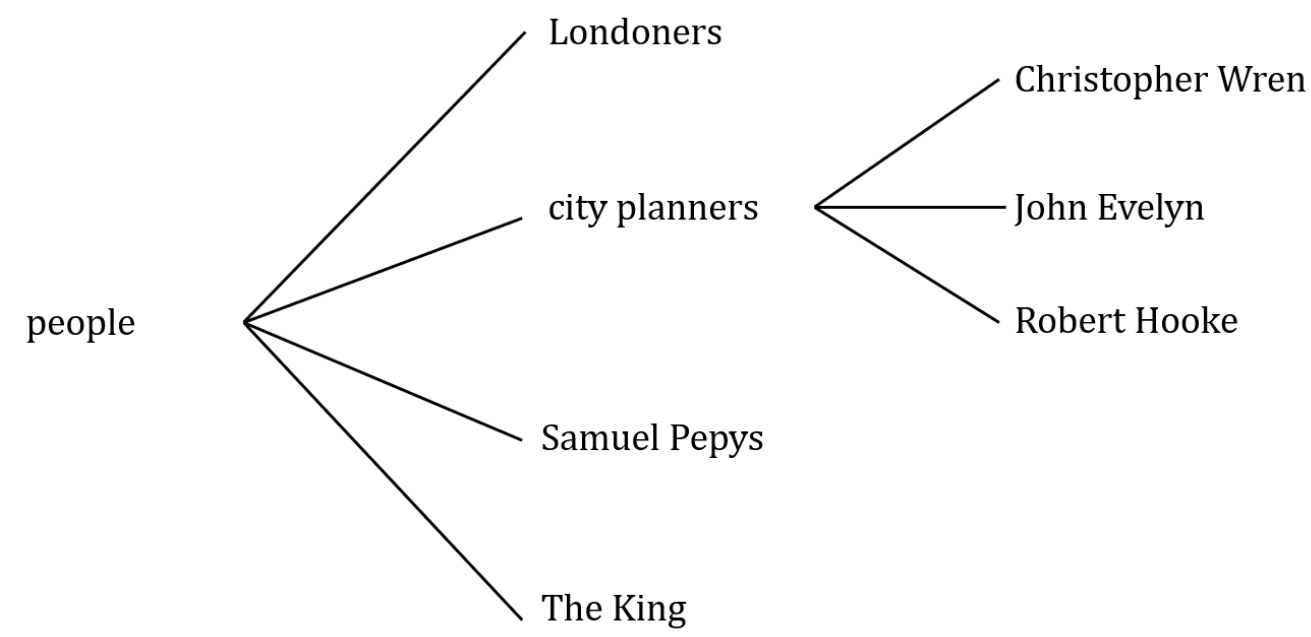




\section{Figure 8}

Classification of People in Text 2

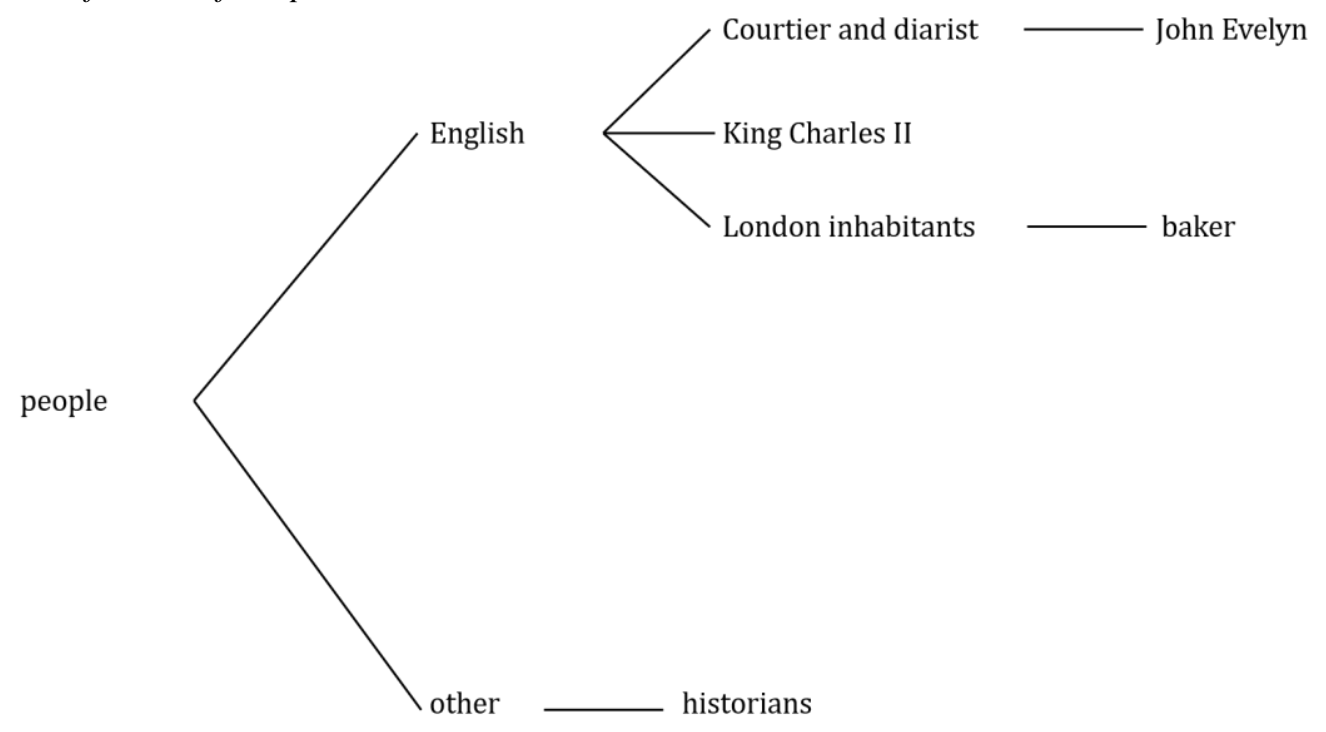

\section{Activity sequences of fire}

Another salient feature of field exemplified in both texts was that sequence of events was specifically revolved around time. Temporal sequences e.g. On Sunday, on Wednesday, on Thursday, in 1665, in the $1670 \mathrm{~s}$ or other generalised abstract temporal locations, such as within a few days of fire ${ }^{i i}$ created an emphasis that the texts organised events in a chronological order. The strategy of organising sequence of events into specific temporal locations is essential in presenting and interpreting history (Martin \& Rose, 2008). Looking at closely the sequence of events, Text 1 maintained a chronological presentation of time thus constituting a 'grand narrative' (Coffin, 2006a) of the fire. Meanwhile, Text 2 jumped around in time when presenting two interrelated historical periods. In text time, the period of Great Fire was presented preceding the period of The Black Death. In field time, The Black Death was the period that happened before The Great Fire. Shifts in time presented in the texts are essential to phasing historical events chronologically (Martin, 2003).

An alternative means to look at how field in Text 1 and Text 2 was construed can be seen from a dynamic perspective of field (Doran \& Martin, 2020 b) in that phenomena is construed dynamically through activities. Text 1 generally construed field of History through momented activities (expectancy series) as in

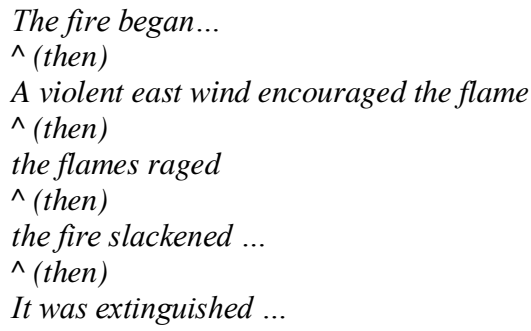

The series of above activities were combined by the specific circumstances to indicate the precise time in which each activity occurs. All the activities in the series were geared towards recounting the happening of the Great Fire of London.

In Text 2, contrastively, the field tended to be geared towards the implication of the Great Fire of London on several domains. In Doran and Martin's (2020b) terms, this is called an implication series. This refers to the causal or conditional relations of entailment which are apparent for the purpose of explaining, such as

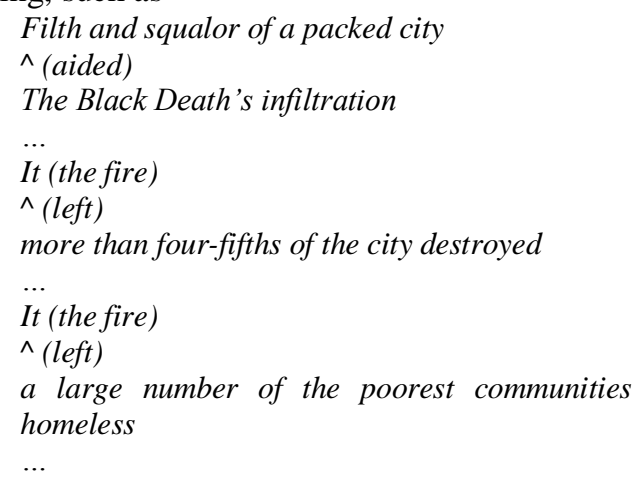

Apart from the congruent realisations of activities, Text 2 also entailed series of nominalised activities resulted from the Great Fire of London to the invasion and colonialization of English in Australia, for example 'Though the eventual colonisation and invasion by the English in Australia wasn't till much later...'

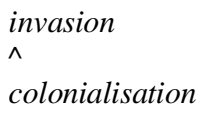

The nominalised activities above indicates the abstraction of cause-effect relationships construed in historical discourses (Coffin, 2006a, 2006b). They 
packed such relations into a non-congruent ones to allow for "a precise nominal formulation of potentially complex causes and effects" (Martin, $2013 \mathrm{a}$, p. 31). In addition, the use of such noncongruent realisations of cause-effect relations signals that the knowledge of history construed in the texts were uncommon sense.

\section{Mode}

This sub-section shifts gears into the presentation and discussion relevant to the variables of mode, especially on the domain of feedback potentials and identification (results relevant to periodicity is presented in the genre organisation section).

\section{Feedback potentials of the information presented}

Within monologic vs. dialogic axis, both texts were relatively monologic in that feedback potentials are very limited. They primarily functioned to provide information regarding Great Fire of London through the channel of writing. In this particular case, language is used to construe historical events (Martin \& Rose, 2008), not accompanying them (see relevant discussion on field subsection). Although Text 2 used several questions to indicate shifts between stages, these questions were not directed to invite answers from the readers. Rather, the questions were used to scaffold method of developments of the text (see genre organisation section). In addition, there were not many voices included in the texts, thus signalling that the texts were monologues. The authors were primary appraisers of the discourse. Thus, they dominated the flow of knowledge presented in the texts. Table 1 summarises the choice of appraisers in the texts.

Table 1

\begin{tabular}{|c|c|c|c|}
\hline Appraiser & Text 1 & Appraiser & Text 2 \\
\hline author & 8 & author & 20 \\
\hline Londoners & 2 & historians & 3 \\
\hline \multirow[t]{3}{*}{ The Monument } & 1 & reports & 1 \\
\hline & & John Evelyn & 1 \\
\hline & & The whole city & 1 \\
\hline Total & 11 & Total & 26 \\
\hline
\end{tabular}

\section{Identification of participants}

In terms of accompanying - constituting field cline, IDENTIFICATION resources can be used to indicate that the texts constitute the field. As has been mentioned in field section, the texts utilised generic references and specialised lexis to constitute the field of history. In addition, the texts also used several text and locative references to indicate that the presumed information can be obtained from the text (Martin \& Rose, 2007) such as within a few days of fire, so what does this have to do with Black Death, and so how does Australia tie into this. Furthermore, the texts made a significant use of esphoric references to signal that the presumed information is revealing themselves within the same nominal group (Martin, 1992) as in the early hours of the morning, the evening of that day, and the hills of Hampstead and Highgate. Having said this, it can be assumed that the texts are relatively contextdependent in that readers may render the information presented without being reliant to the surrounded context. The use of such phoricity also indicated that the texts were delivered through the channel of writing as language was used to establish the going-on.

However, apart from utilising IDENTIFICATION resources to constitute the field, both texts deployed a considerable amount of homophoric reference to identify certain people and historical artefacts. The use of homophoric reference, in this particular case, was not indicating that the text is context-dependent. Rather, homophoric reference was used to address potential readers who share similar cultural and communal values. The use of this kind of reference contribute to the creation of shared solidarities between members of particular communities (Tann, 2010, 2013) and will be discussed in details in Tenor section.

\section{Tenor}

This sub-section turns its attention to the discussion on the way language construes interpersonal relations between interlocutors, especially in terms of social relations and evaluations.

\section{Social relations of events and potential readers}

Several identification resources from both texts contributed to the creation of solidarity. Homophoric references, as mentioned previously, play an essential role in construing a shared solidarity between the writers and potential audiences (Tann, 2013). Homophoric references in the texts were realised by proper noun referring to the name of people and location or places, for example London, Pudding Lane, London Bridge, Christopher Wren, The Monument (Text 1); and The Plague, Thames Street, John Evelyn, The Black Death, St. Paul's Cathedral (Text 2). Regarding this, it is suggested that the texts are written for those who share a similar cultural background with the authors (particularly for British and Australian people). Such examples corroborate Martin's (1992) notion that homophoric reference aligns readers with the presumed information which is inherently given or unique within communities. In this particular case, the presumed information available in cultural reservoir is used to align readers with a shared communal values (Martin, 2006) presented in the texts.

\section{Evaluations of the fire}

The aspect of solidarity was strengthened by the proliferation of other interpersonal meanings colouring the nuance of the texts. Evaluative resources from APPRAISAL analysis captured the writers' attempts on aligning readers to the negativity of the Great Fire. The evaluation of the 
fire was mainly realised by APPRECIATION sources. The fire was considered worst because it destroyed many public and private buildings (Text 1); it kills people and demolished many homes (Text 2). In addition to the evaluation of fire, Text 2 used a significant amount of appreciation to evaluate other events, The Black Death. However, The Black Death was construed less explicitly than the fire, for example, it hit London hardest, it spreads through..., The Black Death's infiltration. Having said this, in term of evaluation, Text 2 tend to be implicit (there are 11 out of 16 invocation instances of evaluation) thus suggesting that the author mitigates the impact of the negativity of her evaluation (Martin \& White, 2005).

To further dramatize the evaluations, a significant amount of graduation resources was used in both texts. Several intensification graduations were e.g. worst fire, the flames again burst forth (Text 1); and It left more than four-fifths of the city destroyed, the Great Fire demolished (Text 2) were used to amplify negativity of the fire. To tune up impact of the fire, quantification graduations were deployed in both texts to emphasise the number of damages, for example

It destroyed a large part of the City of London, including most of the civic buildings, old St. Paul's Cathedral, 87 parish churches, and about 13,000 houses (Text 1)

The fire that engulfed London destroyed 13,000 houses, nearly 30 churches and public houses... the fire left 100,000 people homeless (Text 2)

In terms of status, ENGAGEMENT resources were used to identify the inclusion of voices in the discourse. According to Martin and White (2005), ENGAGEMENT concerned intersubjective positioning of the readers in an alignment of values shared in the texts. In written monologic texts, the inclusion of voices other than those of the writers was possibly done through several ways e.g. projection, modality and concession. In doing so, engagement resources legitimise the importance of the topic being presented (Hood, 2010) thus contributing to readers' alignment to the values presented within the texts.

As far as engagement sources are concerned, both texts tend to be monoglossic. This suggests that the texts legitimised themselves as the most dominant knowledge source by utilising a minimum amount of ENGAGEMENT source. In relation to status being construed in the discourse, it indicates that the texts have more power than the readers thus closing the opportunity of challenging information presented in the texts. Text 1 only used five engagement sources ( 1 modality: negation and 5 concessions). The use of concession sources in this text primarily dealt with countering expectancy regarding flows of some events as exemplified in on Thursday it was extinguished, but on the evening of that day the flames again burst forth...; and countering the attribute of locations Some fled to the hills of Hampstead and Highgate, but Moorfields was the chief refuge of the houseless Londoners.

Text 2 also used a relatively similar amount of ENGAGEMENT resources. There were 2 concessions, 4 projections, and 1 modality sources observed in the text. One important functions of projections sources in this text was that they set up attributions towards other people's insight regarding the events. These attributions were realised both in direct and impersonalised attributions (Feez et al., 2008) orienting towards evaluations of events or entities presented in the text such as John Evelyn, courtier and diarist, wrote "... ", Though historians disagree, the disease is thought to have... By doing this, the text introduced other sources of evaluation consolidating the significance of the events. However, such ENGAGEMENT sources did not change the roles of the texts in terms of positioning readers not to challenge the view presented, rather they worked to orient them to share similar evaluations towards the events (Tann, 2013).

\section{Genre organisations}

After considering the configurations of meaning within register variables realised by discourse semantics resources, this paper is now in a position to elaborate the interaction between field, mode, and tenor in the overall genre organisation. Genre utilises relevant features of context of situations to establish subject matter and types of activity, to enact social relations between interlocutors in particular discursive practices, and to organise them in specific ways (Bowcher, 2017; Martin, 1992; Martin \& Rose, 2008; Tann, 2017).

\section{Genre of Great Fire of London}

This text was a typical example of a historical recount because the text functions to inform readers about a significant historical event organised in chronological time order (Coffin, 2006a). This text consisted of two central stages: Background and Record of Events; and one optional stage: Deduction (Coffin, 2006a; Martin \& Rose, 2008). The overall genre staging of this text is provided in Table 2.

Table 2

Genre Organisation of Great Fire of London

\begin{tabular}{ll}
\hline Background & Great Fire of London, (September 2-5, 1666), the worst fire in London's history.... \\
Record of Events & On Sunday, September 2, 1666, the fire began accidentally.... \\
& Within a few days of the fire, three different plans were presented... \\
(Deduction) $^{\text {iii }}$ & The Great Fire is commemorated...
\end{tabular}


There are some interesting phases within Record of Event stages that can be explored in a more delicate way. For example, there are two Minor Deduction stages (see Table 3) signalling evaluation towards the significance of event or people involved in the text. Following Coffin (2006a) this phase is obviously marked by evaluation sources and higher-level periodicity (hyperNew) indicating an accumulation of information that has been presented.

Table 3

Stages and Phases of Great Fire of London

\begin{tabular}{lll}
\hline Stages & Text & Phase \\
\hline Background & $\begin{array}{l}\text { Great Fire of London, (September 2-5, 1666), the worst fire in London's } \\
\text { history... }\end{array}$ & $\begin{array}{l}\text { summarising } \\
\text { event }\end{array}$
\end{tabular}

Record of Events

On Sunday, September 2, 1666, the fire began accidentally in the house of the king's baker in Pudding Lane near London Bridge...

recounting the period of fire

(Minor Deduction) Many interesting details of the fire are given in Samuel Pepys's Diary. evaluating the fire

Record of Events

Within a few days of the fire, three different plans were presented to the king for the rebuilding of the city, by Christopher Wren, John Evelyn, and Robert Hooke...

(Minor Deduction)

Nevertheless, Wren's great work was the erection of St. Paul's Cathedral...

evaluating

people's works

(Deduction)

The Great Fire is commemorated by The Monument...

evaluating the significance of the fire

In terms of overall genre organisations, the writer scaffolds method of developments utilising higher-level periodicity in that information in the Background serves to predict what to come next; while the information in Deduction stage provides a consolidation towards the significance of the event (Coffin, 2006a). Negative appreciation towards the fire in Background stage clearly flagged the prosody of the negativity of the fire. The fire was the participant that was frequently tracked, establishing the longest reference chain in the text. It was suggested that this text put a considerably close attention to the fire. The fire received the most prominent textual position and became the entity that carried evaluative loads in Background, indicated by its position as thematic elements as well as its evaluation Great Fire of London - the worst fire - it.

Records of Event was generally marked by temporal shift indicated by marked Theme, for example on Sunday, on Wednesday, on Thursday, but on the evening of that day, and within a few days of fire. The use of temporal marker indicating shifts in time is crucial in historical recounts to arrange the events in a chronological manner (Coffin, 2006a, 2006b).

In terms of participants identification, there was a stability of focus in this text, keeping track on the fire as the most salient participant (the fire - the flames (synonymy) - the fire - it - the flames (synonym) - the fire - many interesting details of the fire). In the second Record of Event stage, there was a shift from recounting the period of fire into the activities happened aftermath. The focus participant also shifted, from the fire to the plans and the associated people three different plans - none of these plans; Christopher Wren - Wren's great work; Robert Hooke - Hooke's task.

\section{Genre of The Plague, Australia, and The Great Fire of London}

There were several considerations in identifying the genre of this text. Firstly, the writer reproduced historical events through the medium of mass media. Thus, broadly speaking this text can be considered one type of media genres. Having said this, several essential components of generic organisation in media texts can come into play, e.g. the use of Headline and Byline (Feez et al., 2008). The text did not present destabilising events. Rather, it tried to explain the consequences of several historical events. Secondly, the text resembled characteristics of historical explanation in which the text tried to foreground the consequence of historical events presented, not on the chronological order of events (Coffin, 2006a; Martin \& Rose, 2008). Regarding this, this paper thus puts The Plague, Australia, and The Great Fire of London as a type of evolving genre (Media Historical Explanation). Generic organisations of the text can be seen in the Table 4 .

According to Table 4, the author of the text deployed higher-level periodicity to scaffold the information delivered to the readers. The text was centred around the influence of the Great Fire on other historical events e.g. the Black Death and 
colonialization and invasion in Australia. Textually, the questions "How did the Great Fire of London influence many other historical events?" carried the most prominent textual load, predicting the overall development of the text (Martin \& Rose, 2007). The text then provided other questions to indicate shifts in stages. The shifts between stages were done by delaying knowledge about the related consequences of the events. However, as far as results of the analysis are concerned, the questions posed to shift stages did not change the mode of the discourse because the questions were not genuinely used to get direct feedback. This implies that although the text utilises question to signals shifts in terms of stages and topic, the possibility of having potential direct feedback from the readers is minimal. Thus, it can be said that the question posed in the text is not originally used to allows direct interaction with readers, rather to scaffold method of developments of the text.

Table 4

Stages and Phases of The Plague, Australia, and The Great Fire of London

\begin{tabular}{|c|c|c|c|}
\hline Stages & Text & Phase & \\
\hline Headline & The Plague, Australia and The Great Fire of London & & \\
\hline Byline & By Lulu Morris & & \\
\hline Input & $\begin{array}{l}\text { How did the Great Fire of London influence many other historical events? } \\
\text { On this day, on September 2nd, 1666, in the early hours of } \\
\text { the morning, a fire broke out... }\end{array}$ & $\begin{array}{l}\text { identifying } \\
\text { phenomenon } \\
\text { leading to } \\
\text { change }\end{array}$ & $a$ \\
\hline Consequence & $\begin{array}{c}\text { So what does this have to do with the Black Death? } \\
\text { The fire that engulfed London destroyed... }\end{array}$ & $\begin{array}{l}\text { summarising } \\
\text { identified } \\
\text { phenomenon }\end{array}$ & the \\
\hline
\end{tabular}

According to reports, the fire left 100,000 people homeless. attribution John Evelyn, courtier and diarist, wrote...

In 1665, just a year before the Great Fire the so-called great plague hit London hardest...

presenting another phenomenon

Though historians disagree, the disease is thought to have been controlled after the Great Fire burnt through...

elaborating the consequence of the first phenomenon

Consequence So how does Australia tie into this?

Because the Great Fire demolished so many homes, it left...

elaborating the consequence of the Though the eventual colonisation and invasion by the English in Australia..

first phenomenon

In terms of participant identification, similar to Great Fire of London text, the fire was identified as the most salient participant in the text. The tracking of this participant was realised by several ways, including synonymy and pronominal as in a fire - it - the blaze (synonymy) - the fire - an inferno (bridging) - the blaze - it - the fire - the fire dreadful flames - the Great Fire - the Great Fire it - the Great Fire. When shifting gears to presenting another event, the reference chain also changed. In this case the text also put a close attention to the plague, by tracking it as in the plague - the so-called plague - it - the disease (synonymy) - the disease - the dreaded disease. These considerably long chains referring to the fire and the disease suggest that the text directs readers attention towards these two events. Regarding these two events, the text aimed to draw a causal link that leads to the interpretation of consequences. This was signalled by several causal markers e.g. because, though, so, as and so on. Having said this, it can be said that The Plague, Australia, and The Great Fire of London foregrounded causal relations between events, not on the chronological order of time (Coffin, 2003; Martin \& Rose, 2008).

\section{CONCLUSION}

This paper has explored in detail the organisation of history genres recontextualised in the media by stepping through components of register instantiated by various discourse semantics resources. What can be said about history genres in the media, as far as results of analysis and discussion are concerned, is that there is a tendency that history can be reconstrued in some different ways, be it similar or completely different. As has been seen throughout this paper, one historical event is reconstrued in two different ways. Text 1 informs readers about the fire and its significance in a chronological manner. Text 2 provides an explanation of the influence of the Great Fire to other historical events. In terms of genre, Text 1 is considered a stable one as its stages and phases conforms typical patterns of historical 
recount, similar to the ones that appear in the discipline of History. Meanwhile, Text 2, as discussed previously, can be considered an 'evolving' one in that it is one example of historical explanation genre that is reproduced and published in mass media. In terms of register variables, several similarities and differences can be drawn, especially on their orientation towards activities, shared solidarities, feedback potentials, and higher-level organisation of information. The main differences between them lie on the overall social purpose that the texts want to achieve. Considering the findings, though still at the initial stage, this paper offers a great insight into the relations between discourse semantics resources and register with regards to the development of history genres reproduced through online media. Such findings expand and integrate the repertoire of historical meaning making resources beyond the educational field, of which is crucial to understand historical discourses in online media.

\section{ACKNOWLEDGEMENT}

The author would like to thank to the reviewers for their very useful comments and the improvements they suggest on the earlier version of this article. The author would also like to deliver his appreciation to the LPPM (Board of Research and Community Services) of Universitas Ahmad Dahlan for their generous funding to support the enactment of the study reported on this article.

\section{REFERENCES}

Bangga, L. A. (2018). Sundanese transitivity: A first step into the description [Unpublished doctoral dissertation]. The University of Sydney.

Bangga, L. A., \& Lukmana, I. (2019). Recontextualising NAPLAN: A functional analysis of evaluations in media texts. Indonesian Journal of Applied Linguistics, 9(1), 128-137. https://doi.org/10.17509/ijal.v9i1.15215

Bednarek, M., \& Caple, H. (2017). The discourse of news values: How news organisations create newsworthiness. Oxford University Press.

Bowcher, W. L. (2017). Field, tenor and mode. In T. Bartlett \& G. O'Grady (Eds.), The routledge handbook of systemic functional linguistics (pp. 391-403). Routledge. https://doi.org/10.4324/9781315413891.ch24

Caldwell, D., Walsh, J., Vine, E. W., \& Jureidini, J. (Eds.). (2016). The discourse of sport: analyses from social linguistics. Routledge.

Carvalho, A. (2008). Media(ted) discourse and society: Rethinking the framework of critical discourse analysis. Journalism Studies, 9(2), 161-177. https://doi.org/10.1080/14616700701848162
Christie, F., \& Derewianka, B. (2008). School discourse: Learning to write across the years of schooling. Continuum.

Coffin, C. (2003). Reconstructs of the past settlement or invasion? The role of judgement analysis. In J. R. Martin \& R. Wodak (Eds.), Re/reading the past: Critical and functional perspectives on time and value (pp. 219-246). John Benjamins.

Coffin, C. (2004). Learning to write history: The role of causality. Written Communication, 21(3), 261-289. https://doi.org/10.1177/0741088304265476

Coffin, C. (2006a). Historical discourse: The Language of time, cause, and evaluation. Continuum.

Coffin, C. (2006b). Learning the language of school history: The role of linguistics in mapping the writing demands of the secondary school curriculum. Journal of Curriculum Studies, 38(4), 413-429. https://doi.org/10.1080/00220270500508810

Derewianka, B., \& Jones, P. (2012). Teaching language in context. Oxford University Press.

Doran, Y. J. (2018). The discourse of physics: Building knowledge through language, mathematics and image. Routledge.

Doran, Y. J., \& Martin, J. R. (2020a). Describing languages, understanding language: Systemic functional theory and description. In J. R. Martin, Y. J. Doran, \& G. Figueredo (Eds.), Systemic functional language description: making meaning matter (pp. 1-32). Routledge.

Doran, Y. J., \& Martin, J. R. (2020b). Field relations: Understanding scientific explanations. In J. R. Martin, K. Maton, \& Y. J. Doran (Eds.), Studying science: Knowledge, language, pedagogy. Routledge.

Dreyfus, S., Humphrey, S., Mahboob, A., \& Martin, J. R. (2016). Genre pedagogy in higher education: The SLATE project. Palgrave Macmillan.

Emilia, E., Habibi, N., \& Bangga, L. A. (2018). An analysis of cohesion of exposition texts: An Indonesian context. Indonesian Journal of Applied Linguistics, 7(3), 515-523. https://doi.org/10.17509/ijal.v7i3.9791

Feez, S., Iedema, R., \& White, P. R. R. (2008). Media literacy. NSW AMES.

Garrioch, D. (2016). 1666 and London's fire history: A re-evaluation. The Historical Journal, 59(2), 319-338. https://doi.org/10.1017/S0018246X15000382

Halliday, M. A. K., \& Martin, J. R. (1993). Writing science: Literacy and discursive power. The Falmer Press.

Hao, J. (2015). Construing biology: An Ideational Perspective [Unpublished doctoral dissertation]. The University of Sydney.

Hood, S. (2010). Appraising research: Evaluation in 
academic writing. Palgrave Macmillan.

Jeffries, N., Featherby, R., Wroe-Brown, R., Betts, I., Harrington, S., \& Richardson, B. (2014). "Would I were in an alehouse in London!": A finds assemblage sealed by the Great Fire from Rood Lane, city of London. Post-Medieval Archaeology, 48(2), 261-284. https://doi.org/10.1179/0079423614Z.0000000 0057

Kartika-Ningsih, H., \& Rose, D. (2018). Language shift: analysing language use in multilingual classroom interactions. Functional Linguistics, 9(2018), 1-22. https://doi.org/10.1186/s40554018-0061-0

Liu, F. (2018). Lexical metaphor as affiliative bond in newspaper editorials: A systemic functional linguistics perspective. Functional Linguistics, 5(2), 1-14. https://doi.org/10.1186/s40554-0180054-z

Macnaught, L., Maton, K., Martin, J. R., \& Matruglio, E. (2013). Jointly constructing semantic waves: Implications for teacher training. Linguistics and Education, 24(1), 5063. https://doi.org/10.1016/j.linged.2012.11.008

Martin, J. R. (1992). English text: System and structure. John Benjamins.

Martin, J. R. (2003). Constructing time and value: Grammar for interpretation. In J. R. Martin \& R. Wodak (Eds.), Re/reading the past: Critical and functional perspectives on time and value (pp. 19-60). John Benjamins.

Martin, J. R. (2006). Genre, ideology and intertextuality: A systemic functional perspective. Linguistics \& The Human Sciences, 2(2), 275-298. https://doi.org/10.1558/lhs.v2i2.275

Martin, J. R. (2013a). Embedded literacy: Knowledge as meaning. Linguistics and Education, 24(1), 23-37. https://doi.org/10.1016/j.linged.2012.11.006

Martin, J. R. (2013b). Systemic functional grammar: A next step into theory---axial relations. Higher Education Press.

Martin, J. R. (2018). Introduction. Interpersonal meaning: Systemic functional linguistics perspective. Functions of Language, 25(1), 219. https://doi.org/10.1075/fol.17018.mar

Martin, J. R. (2019). Discourse semantics. In G. Thompson, W. L. Bowcher, L. Fontaine, \& D. Schönthal (Eds.), The Cambridge handbook of systemic functional linguistics (pp. 358-381). Cambridge University Press.

Martin, J. R., \& Maton, K. (2013). Cumulative knowledge-building in secondary schooling: Guest editors' preface. Linguistics and Education, 24(1), 1-3. https://doi.org/10.1016/j.linged.2012.11.003

Martin, J. R., \& Matruglio, E. (2020). Revisiting mode: Context in/dependency in ancient history classroom discourse. In J. R. Martin, K. Maton, \& Y. J. Doran (Eds.), Accessing academic discourse: Systemic functional linguistics and legitimation code theory (pp. 89-113). Routledge.

Martin, J. R., \& Rose, D. (2007). Working with discourse: Meaning beyond the clause (2nd ed.). Continuum.

Martin, J. R., \& Rose, D. (2008). Genre relations: Mapping culture. Equinox.

Martin, J. R., \& Veel, R. (1998). Reading science: Critical and functional perspectives on discourses of science. Routledge.

Martin, J. R., \& White, P. R. R. (2005). The language of evaluation: Appraisal in English. Palgrave Macmillan. https://doi.org/10.1057/9780230511910

Matruglio, E., Maton, K., \& Martin, J. R. (2013). Time travel: The role of temporality in enabling semantic waves in secondary school teaching. Linguistics and Education, 24(1), 38-49. https://doi.org/10.1016/j.linged.2012.11.007

Matthiessen, C. M. I. M., \& Halliday, M. A. K. (2009). Systemic functional grammar: A first step into the theory. Higher Education Press.

Morris, L. (2017, June 10). The Plague, Australia and the great fire of London. National Geographic. http://www.nationalgeographic.com.au/australi a/the-plague-australia-and-the-great-fire-oflondon.aspx

Myskow, G. (2017). Surveying the historical landscape: The evaluative voice of history textbooks. Functional Linguistics, 4(7), 1-15. https://doi.org/10.1186/s40554-017-0039-3

Myskow, G. (2018). A framework for analyzing evaluative language in historical discourse. Functions of Language, 25(3), 335-362. https://doi.org/10.1075/fol.15053.mys

Oteíza, T. (2020). Historical events and processes in the discourse of disciplinary history and classroom interaction. In J. R. Martin, K. Maton, \& Y. J. Doran (Eds.), Accessing academic discourse: Systemic functional linguistics and legitimation code theory (pp. 177-208). Routledge.

Oteíza, T., \& Pinuer, C. (2013). Valorative prosody and the symbolic construction of time in recent national historical discourses. Discourse Studies, 15(1), 43-64. https://doi.org/10.1177/1461445612466447

Rose, D., \& Martin, J. R. (2012). Learning to write, reading to learn: Genre, knowledge and pedagogy in Sydney school. Equinox.

Schleppegrell, M. J. (2004). The language of schooling: A functional linguistics perspective. Lawrence Elbraum.

Tann, K. (2010). Imagining communities: A multifunctional approach to identity 
management in texts. In M. Bednarek \& J. R. Martin (Eds.), New discourse on language: functional perspectives on multimodality, identity, and affiliation (pp. 163-194). Continuum.

Tann, K. (2013). The language of identity discourse: Introducing a systemic functional framework for iconography. Linguistics and the Human Sciences, 8(3), 361-392. https://doi.org/10.1558/lhs.v8i3.361

Tann, K. (2017). Context and meaning in the Sydney architecture of systemic functional linguistics. In T. Bartlett \& G. O'Grady (Eds.), The routledge handbook of systemic functional linguistics (pp. 438-456). Routledge. https://doi.org/10.4324/9781315413891.ch27

The Editors of Encyclopaedia Britannica. (2014, August 26). Great fire of London. Britannica. https://www.britannica.com/event/Great-Fireof-London

Trigg, S. (2016). Samuel Pepys and the great fire of
London: Trauma and Emotion, Private and Public. In J. Spinks \& C. Zika (Eds.), Disaster, death and the emotions in the shadow of the apocalypse, 1400-1700 (pp. 341-356). Palgrave Macmillan.

Zappavigna, M. (2016). Social media photography: construing subjectivity in instagram images. Visual Communication, 15(3), 271-292. https://doi.org/10.1177/1470357216643220

Zappavigna, M., \& Martin, J. R. (2018). \#Communing affiliation: Social tagging as a resource for aligning around values in social media. Discourse, Context and Media, 22(1), 4-12. https://doi.org/10.1016/j.dcm.2017.08.001

Zhang, D. (2020). Towards a discourse semantic characterisation of the modal particles in Khorchin Mongolian: A case study of an interaction. Journal of Pragmatics, 158(1), 1332. https://doi.org/10.1016/j.pragma.2019.12.013

\footnotetext{
${ }^{\mathrm{i}}$ In SFL, systems are written in small capital letter, following the notation suggested in Martin (2013b) and Matthiessen and Halliday (2009).

ii There are some ambiguities in placing some activity sequences in field time. For example, within a few days of fire, three different plans were presented to the king. The circumstance within a few days of fire does not indicate specifically the time in which this activity took place. It could be best placed in a similar line when the fire burst at The Temple given that this activity took place within a few days of fire which possibly took more than one or two days to happen after the fire started. In addition, considering within a few days of fire, it signals that this activity probably took place inside or not further than the period of fire. Thus, it is possible to place this activity in a similar timeline when the fire was already mastered. Another ambiguity may arise when deciding field time for the river swarmed with vessels filled with persons...; and some fled to the hills of Hampstead and Highgate. There is no definite circumstance of time signalling when this happening took place. Thus, possible interpretation will be that these activities took place during the period of fire, from Sunday to Thursday given that logically people will escape immediately from their house if a fire breaks out. Also, this activity can also take place in the post-fire period given that they will find shelter to live temporarily.

iii Optional Stages of genres are written in bracket (see Martin \& Rose, 2008).
} 